\title{
Spatial patterns of snow accumulation across Belcher Glacier, Devon Ice Cap, Nunavut, Canada
}

\author{
Tyler SYLVESTRE, ${ }^{1}$ Luke COPLAND, ${ }^{1}$ Michael N. DEMUTH, ${ }^{2}$ Martin SHARP ${ }^{3}$ \\ ${ }^{1}$ Department of Geography, University of Ottawa, Ottawa, Ontario, Canada \\ E-mail: luke.copland@uottawa.ca \\ ${ }^{2}$ Geological Survey of Canada, Natural Resources Canada, Ottawa, Ontario, Canada \\ ${ }^{3}$ Department of Earth and Atmospheric Sciences, University of Alberta, Edmonton, Alberta, Canada
}

\begin{abstract}
Ground-penetrating radar (GPR) surveys at a center frequency of $500 \mathrm{MHz}$ were used to determine winter (2007/08) and net annual (2005-07) snow water equivalent (SWE) patterns across the upper parts of Belcher Glacier, Devon Ice Cap, Nunavut, Canada. The GPR measurements were validated against snow depths determined from avalanche probe measurements, and converted to SWE values using densities measured with a down-borehole neutron density probe and in shallow snow pits. Distinct internal reflection horizons (IRHs) in the GPR record were formed during warm summers in 2007 and 2005, and a large rain event in summer 2006 which caused ice to accumulate above the 2005 melt surface. Elevation provides the dominant control on winter SWE distribution across the basin, with surface topography (e.g. gullies) also being locally important. Based on the location where IRHs intersected the ice-cap surface, the basin-wide firn line occurred at an altitude of 1260-1300 m over the period 2005-08. Net mass balance across the accumulation area of Belcher Glacier averaged $0.24 \mathrm{~m}$ w.e. $\mathrm{a}^{-1}$ over the period 2005-07, mainly dependent on altitude. This is a little higher than most previous estimates for the period since the 1960s, although the differences lie within error limits.
\end{abstract}

\section{INTRODUCTION}

The spatial variability of supraglacial snow cover is an important influence on glacier mass balance, and must be known if models of surface melt and mass balance are to be properly initialized. At present, information on snow accumulation patterns on ice masses in Canada's Queen Elizabeth Islands (QEI) has been derived mainly from a sparse network of point measurements, obtained from massbalance stakes, firn cores, snow pits and manual probing (e.g. Koerner, 1966; Cogley and others, 1996; Mair and others, 2005; Colgan and Sharp, 2008). These methods are used to identify the position of end-of-summer surfaces or annual layering, and may also provide information about temporal variability in snow accumulation at each measurement site. Point measurements tend to be labour-intensive and time-consuming, however, and given the complexity of factors that control snow-cover distribution across glaciers and ice caps (e.g. terrain, distance from moisture sources, wind redistribution), they provide little information about the spatial distribution of snow cover at a resolution that approximates the true variability (Deems and others, 2006).

Past studies have demonstrated that ground-penetrating radar (GPR) measurements from moving platforms, at typical frequencies of $\sim 200-1000 \mathrm{MHz}$, can characterize snowcover variability with high vertical and horizontal resolutions along continuous profiles in locations such as Svalbard (Kohler and others, 1997; Pinglot and others, 2001; Pälli and others, 2002; Taurisano and others, 2007; Dunse and others, 2009), Greenland (Maurer, 2006; Dunse and others, 2008) and Antarctica (Spikes and others, 2004; Arcone and others, 2005; Anschütz and others, 2008; Eisen and others, 2008). A previous study on Devon Ice Cap, QEI, with a $8-18 \mathrm{GHz}$ frequency-modulated continuous-wave radar identified almost continuous near-surface reflectors over $1 \mathrm{~km}$ transects near the summit region (Demuth and others, 2007), although these were not used to quantify snow water equivalent (SWE) distribution. Transmitted radar signals are reflected at internal reflection horizons (IRHs) within the snow and firn. Changes in the dielectric properties of the snow and firn that produce these IRHs are typically caused by density and stratigraphic contrasts associated with ice layers (including that formed during end-of-summer freezeup), hoar layers and dense wind-packed layers (Arcone and others, 2004; Dunse and others, 2008). The end-of-winter snowpack typically overlies a distinct, hard and dense crust that is almost continuous across the accumulation area of polar glaciers and ice caps. This late-summer surface (LSS) is readily identifiable in GPR surveys conducted in spring due to the contrast in dielectric properties between it and lowdensity depth hoar that makes up the basal part of the overlying winter snowpack. Measuring the vertical separation between LSS layers in a GPR profile can thus provide quantitative measurements of annual snow/firn layer thicknesses, and SWE values when densities are known (Taurisano and others, 2007).

In this study we use GPR and snow density measurements to determine glacier-wide SWE patterns across Belcher Glacier, Devon Ice Cap, over both single winter (2007/08) and multi-year (2005-07) periods. Snow accumulation patterns have previously been determined for other regions of Devon Ice Cap, such as the summit region and northwest and southerly basins (e.g. Koerner, 1966, 1977; Pinglot and others, 2003; Mair and others, 2005; Colgan and Sharp, 2008), but none have previously been determined for the Belcher basin. The GPR data were collected over $306 \mathrm{~km}$ of track across the accumulation area of Belcher Glacier in May 2008 (Fig. 1), prior to the onset of melt, and compared with point snow depth measurements. Shallow ice cores were used to verify the internal layering identified in the GPR surveys. We also use the GPR data to identify the location of the firn line, and investigate the controls on spatial variability in snow distribution by assessing the 
relationships between GPR-derived snow cover and terrain parameters derived from a digital elevation model (DEM).

\section{STUDY SITE AND METHODS}

\subsection{Study site}

Belcher Glacier $\left(75^{\circ} \mathrm{N}, 82^{\circ} \mathrm{W}\right)$ is the largest tidewater glacier flowing from Devon Ice Cap, and accounts for $\sim 42 \%$ of losses from the ice cap due to calving (Van Wychen and others, 2012). The glacier covers an area of $1180 \mathrm{~km}^{2}$, and ranges in elevation from sea level to $\sim 1920 \mathrm{~m}$ (Fig. 1). Most of the lower glacier $(<\sim 1000 \mathrm{~m})$ is constrained within a well-defined bedrock valley and is fed by a number of tributaries, while the upper glacier comprises an open region that reaches the ice-cap summit and shares drainage divides with the rest of the ice cap. Velocities across the upper glacier are typically $10-20 \mathrm{~m} \mathrm{a}^{-1}$, while velocities along the main trunk in the ablation area increase from $\sim 50 \mathrm{~m} \mathrm{a}^{-1}$ in the upper parts to $>200 \mathrm{~m} \mathrm{a}^{-1}$ at the terminus (Van Wychen and others, 2012). The main moisture source for Belcher Glacier is the North Open Water Polynya, to the southeast of Devon Ice Cap, the existence of which promotes relatively long melt seasons (Wang and others, 2005). The mean annual air temperature at sea level for Devon Island is $-13.6^{\circ} \mathrm{C}$ (Mair and others, 2005), while the mean annual air temperature recorded by an automated weather station at the summit of Devon Ice Cap was $-20.5^{\circ} \mathrm{C}$ for the period 1997-2008 (personal communication from P. Bezeau, 2012). Melt onset dates typically range from late May to mid-July (depending largely upon year and elevation), with freeze-up dates from mid-July to early September. The accumulation area of Belcher Glacier contains a superimposed ice zone, slush zone and lower and upper percolation zones, but there has been no dry or quasi-dry snow zone since at least the mid-2000s (personal communication from T. de Jong, 2012).

\subsection{Ice cores and borehole density profiles}

Five boreholes were drilled to depths of 7-12 $\mathrm{m}$ with a Kovacs Mark II ice corer at elevations of 1060 m (B2), 1390 m (B1), $1515 \mathrm{~m}$ (B5), $1640 \mathrm{~m}$ (B3) and $1860 \mathrm{~m}$ (B4) (Fig. 1). The locations and thicknesses of ice lenses and ice layers in the extracted core sections were logged to establish a visual stratigraphy. Centimeter-scale snow density profiles were obtained in the boreholes using a neutron probe modified from a Wallingford soil moisture probe (Bell, 1969). Several previous studies (e.g. Hawley and others, 2006) have established neutron profiling as a valuable tool in studies of polar firn stratigraphy. The device consists of an annularshaped radioactive source mounted around the centre of a cylindrical detector and incorporated into a sonde slowly pulled up the borehole by an automatic geophysical logging system (Morris and Cooper, 2003). Measurements were made from the base of each borehole to a depth of $\sim 0.45 \mathrm{~m}$ below the surface due to the requirement that the centre of the $\sim 1 \mathrm{~m}$ long sonde be fully contained within the borehole.

This study used neutron probe No. 1524 owned and operated by the Geological Survey of Canada, Natural Resources Canada. Neutron count rates were converted to density estimates through empirical field and laboratory calibration to neutron probe No. 165, which is used as the current standard for the community of practice (Morris, 2008). This was enabled by performing a 'water count' experiment and scaling the measured count rates by the ratio

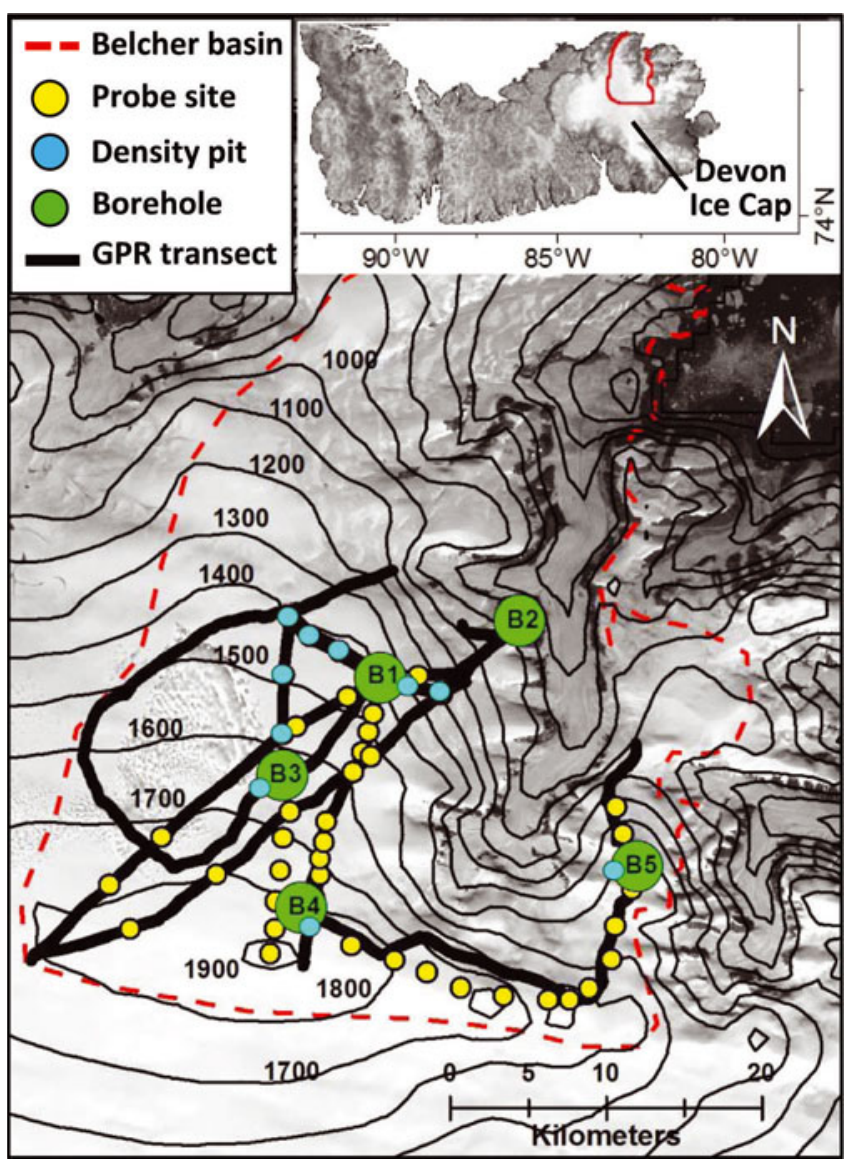

Fig. 1. Boreholes, density pits, snow depth avalanche probe sites and GPR transects used to determine snow accumulation patterns across the upper part of Belcher Glacier. Contours in ma.s.I.

of the probe's water count to that for probe No. 165. In addition, the borehole diameter and sonde offset (i.e. eccentricity within the borehole) were accounted for. For this study, boreholes were mechanically cored to a nominal diameter of $12.2 \mathrm{~cm}$ and the sonde was fully offset against the borehole wall. We estimate that the borehole diameters may have varied by $1-2 \mathrm{~cm}$, and that this amount of variation would influence the estimated density values by approximately $8-10 \%$ (see also Hawley and others, 2008).

\subsection{GPR and snow measurements}

Data were acquired with a Sensors and Software pulseEKKO Pro impulse GPR system with $500 \mathrm{MHz}$ dipole antennas. The receiver and transmitter antennas were mounted in the base of a plastic sled coupled to the surface and towed by snowmobile at a speed of $\sim 10 \mathrm{~km} \mathrm{~h}^{-1}\left(2.78 \mathrm{~m} \mathrm{~s}^{-1}\right)$. Traces were sampled at a temporal resolution of $0.2 \mathrm{~ns}$ over a total time window of $500 \mathrm{~ns}$, stacked 16 times, and recorded every $0.2 \mathrm{~s}$ along transects. An integrated single-frequency GPS receiver recorded a position header in every tenth GPR trace, with unique coordinates calculated for every trace by assuming a constant travel speed between GPS positions. The GPR transects were designed to sample a wide variety of terrain and elevation ranges across Belcher Glacier, but could not be undertaken in a grid-like pattern for reasons related to safety of travel (e.g. crevasses) and logistics (e.g. travel distance from base camp at B2; Fig. 1).

Post-processing of GPR data used signal saturation correction ('dewow') to remove the low-frequency response 
Table 1. Density values, radio-wave velocities and average net annual SWE accumulation rates derived from the 2005-07 GPR measurements on Belcher Glacier compared to previous studies on Devon Ice Cap ( \pm standard deviation)

\begin{tabular}{|c|c|c|c|c|c|c|c|c|}
\hline \multirow[b]{2}{*}{ Elevation range } & \multicolumn{4}{|c|}{ This study } & \multirow{2}{*}{$\begin{array}{c}\text { Colgan and } \\
\text { Sharp (2008) } \\
\text { 1963-2004/05 } \\
\text { SWE* }\end{array}$} & \multirow{2}{*}{$\begin{array}{c}\text { Mair and } \\
\text { others }(2005) \\
\text { 1963-2000 } \\
\text { SWE }\end{array}$} & \multirow{2}{*}{$\begin{array}{c}\text { Pinglot and } \\
\text { others (2003) } \\
\text { 1963-98 } \\
\text { SWE }\end{array}$} & \multirow{2}{*}{$\begin{array}{c}\text { Koerner } \\
(1977) \\
1963-74 \\
\text { SWE }\end{array}$} \\
\hline & $\begin{array}{c}\text { 2005-07 } \\
\text { density }\end{array}$ & $\begin{array}{c}\text { Borehole density } \\
\text { source* }\end{array}$ & $\begin{array}{c}\text { Radio-wave } \\
\text { velocity }^{\dagger}\end{array}$ & $\begin{array}{c}\text { 2005-07 } \\
\text { SWE }\end{array}$ & & & & \\
\hline ma.s.l. & $\mathrm{kg} \mathrm{m}^{-3}$ & & $\mathrm{~m} \mathrm{~ns}^{-1}$ & m w.e. $a^{-1}$ & m w.e. $a^{-1}$ & m w.e. $a^{-1}$ & m w.e. $a^{-1}$ & m w.e. $a^{-1}$ \\
\hline $1300-1400$ & 618 & B1 (1390 m) & 0.197 & $0.26 \pm 0.14$ & & 0.13 & & \\
\hline $1400-1500$ & 523 & Mean B1 and B5 & 0.208 & $0.31 \pm 0.09$ & $0.22 \pm 0.09$ & 0.22 & & \\
\hline $1500-1600$ & 427 & B5 (1515 m) & 0.220 & $0.24 \pm 0.07$ & $0.20 \pm 0.07$ & 0.14 & & \\
\hline 1600-1700 & 454 & B3 (1640 m) & 0.217 & $0.25 \pm 0.07$ & $0.22 \pm 0.03$ & 0.16 & & \\
\hline $1700-1800$ & 341 & B4 (1860 m) & 0.233 & $0.24 \pm 0.06$ & & & & \\
\hline 1800-1900 & 341 & B4 (1860 m) & 0.233 & $0.27 \pm 0.08$ & $0.25 \pm 0.06$ & 0.24 & 0.23 & 0.22 \\
\hline Overall mean & & & & 0.24 & 0.22 & 0.18 & 0.23 & 0.22 \\
\hline
\end{tabular}

*Derived from borehole neutron probe measurements.

'Derived from eqns (2) and (27) of Kovacs and others (1995).

*Average of measurements from different basins across Devon Ice Cap.

common at the start of traces, frequency filtering (vertical bandpass), radar gain adjustments (Spreading and Exponential Calibrated Compensation; SEC2) and trace editing (removal of traces collected when the snowmobile was stationary). These steps provided a visually optimized image that allowed IRH to be identified as distinctive bands of high reflectivity, which were then picked automatically using a pulse-detection routine in Sensors and Software IcePicker R4 software. The automatic GPR picks were checked manually and compared against snow depths to the 2007 late summer surface (LSS-07) determined from measurements with a metal avalanche probe every $\sim 1-4 \mathrm{~km}$ across the upper part of the basin (Fig. 1). Five depths were recorded at each probe location (central point, and $\sim 2 \mathrm{~m}$ away in each cardinal direction), and the average of these values is presented here. The probe depths were checked against visual identification of LSS-07 in $\sim 1 \mathrm{~m}$ deep snow pits distributed across the study area and at each borehole location (Fig. 1). Densities for the 2007/08 layer were measured in each snow pit by weighing the contents of a $250 \mathrm{~cm}^{3}$ metal snow scoop with an electronic scale, with the reported value consisting of the average of three samples taken at equally spaced intervals on each vertical pit wall. The density of the LSS-05 to LSS-07 layer was determined from the mean of the neutron probe measurements over that depth range in each borehole.

Errors in IRH picking were difficult to assess since they depend on factors such as the variability in snowmobile travel speed along the survey line, the signal-to-noise ratio of the reflected event where the original return was weak, and the ability to clearly identify the snow layer (Kohler and others, 1997; Pälli and others, 2002; Parry and others, 2007). Picking errors were assumed to lie between $1 / 20$ and $1 / 10$ of the wavelength used (Kohler and others, 1997; Anschütz and others, 2008; Dunse and others, 2008), which corresponds to a depth error of approximately \pm 0.02 to $\pm 0.04 \mathrm{~m}$ at a center frequency of $500 \mathrm{MHz}$.

We calculated the radio-wave velocity (RWV) in the upper snowpack by using the relationship between RWV and density described by Kovacs and others (1995). This equated to a RWV of $0.234 \mathrm{~m} \mathrm{~ns}^{-1}$ for snow with a mean density of $330 \mathrm{~kg} \mathrm{~m}^{-3}$, as measured in the snow pits for the
2007/08 layer. Densities recorded by the neutron density probe between LSS-05 and LSS-07 varied between 341 and $618 \mathrm{~kg} \mathrm{~m}^{-3}$, mainly dependent on altitude, so a different RWV was applied for each $100 \mathrm{~m}$ elevation band, ranging between 0.233 and $0.197 \mathrm{~m} \mathrm{~ns}^{-1}$. (Table 1). To verify the appropriateness of these RWVs, snow depths to LSS-07 determined with the avalanche probe were compared to the computed depths of IRHs in GPR returns from the same location. A RWV of $0.200 \mathrm{~m} \mathrm{~ns}^{-1}$ provided the best fit to these data $\left(r^{2}=0.98\right)$. The difference between this value and the RWV values used in the calculations could be due to factors such as high-density ice lenses in the snowpack that were not properly sampled with our density measurement procedure, or the presence of water in the near-surface due to radiation-induced melting (although air temperatures were always below freezing during GPR profiling). It is also possible that the picked GPR return originated from within the LSS-07 layer, rather than from its surface as measured with the avalanche probe, although we have no data to verify this. The difference (of $0.034 \mathrm{~m} \mathrm{~ns}^{-1}$ ) between the RWVs derived from the snow densities based on neutron probe and avalanche probe measurements would generate variations in calculated snow layer thicknesses of up to $17 \%$. When combined with potential errors from IRH picking and density measurements, we estimate that the maximum errors in our SWE determinations are $\sim 15-20 \%$.

\section{RESULTS}

\subsection{Overall IRH patterns}

The GPR recorded strong near-surface layering at higher elevations throughout the study region (Figs 2c and 3c). In borehole $5(1515 \mathrm{~m})$, densities increased rapidly from $\sim 400$ to $\sim 550 \mathrm{~kg} \mathrm{~m}^{-3}$ at $\sim 0.65 \mathrm{~m}$ depth (Fig. 2a). This depth correlated with the top of the LSS-07 layer identified in snow pits and a thick ice layer in the visual stratigraphy (Fig. 2b). We interpret this density change to have produced the first continuous IRH throughout the GPR profile (Fig. 2c). Below this layer, the next major IRH matched the $\sim 1.30 \mathrm{~m}$ depth of the next major density increase (from $<400 \mathrm{~kg} \mathrm{~m}^{-3}$ to $>500 \mathrm{~kg} \mathrm{~m}^{-3}$ ). The visual core stratigraphy at this depth 


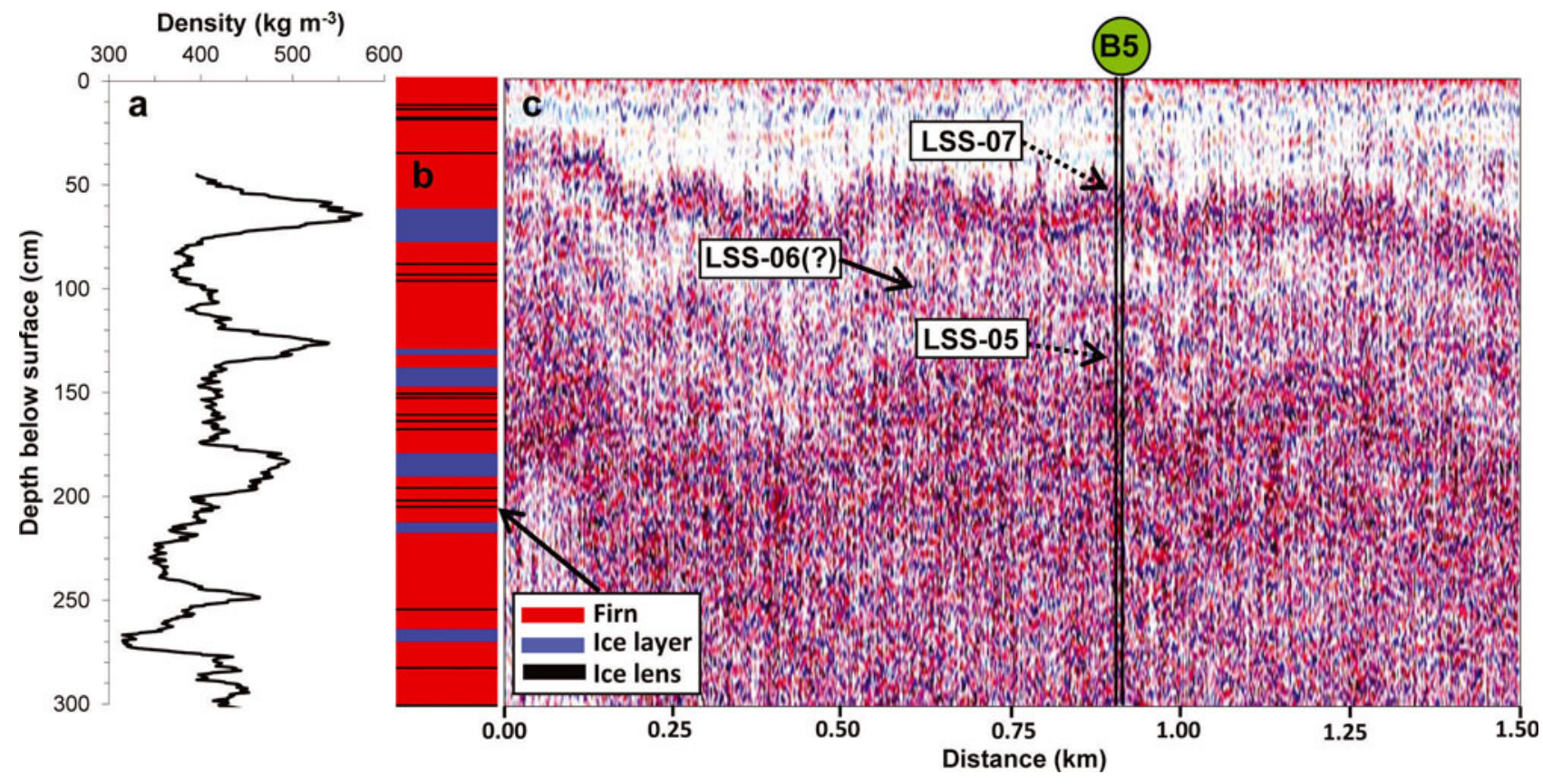

Fig. 2. Results from borehole 5 at $1515 \mathrm{~m}$ : (a) neutron probe density data; (b) visual core stratigraphy; (c) $1.5 \mathrm{~km}$ long GPR trace centered around borehole; dotted arrows point to location of LSS-05 and LSS-07 picked by IcePicker R4 software. Possible location of LSS-06 is marked, but was not picked due to weak return.

showed a series of ice layers and lenses of varying thickness (Fig. 2b). As explained in Section 3.3, we infer this reflection to be LSS-05, with the weaker reflector above it (and below LSS-07) likely representing LSS-06.

At borehole $3(1640 \mathrm{~m})$, the first major IRH in the GPR profile (Fig. 3c) corresponded with a sharp density peak of $530 \mathrm{~kg} \mathrm{~m}^{-3}$ at $0.45-0.50 \mathrm{~m}$ depth in the neutron probe profile (Fig. 3a). It also coincided with the first major zone of ice layering observed in the snow pits, avalanche probe measurements and visual core stratigraphy (Fig. 3b), and is assumed to represent LSS-07. Below this there was a minor density peak at $\sim 0.95 \mathrm{~m}$ depth (Fig. 3a), which appeared as a faint but continuous IRH (Fig. 3c) that is likely associated with LSS-06. However, no ice layers were recorded in the ice-core stratigraphy at this position (Fig. 3b). The neutron probe record shows the next prominent density peak at $1.35 \mathrm{~m}$ depth (Fig. 3a), which correlated well with a distinct IRH in the GPR trace (Fig. 3c). Visual core stratigraphy showed that thick ice layers and ice lenses were also present here (Fig. 3b), and we take this layer to represent LSS-05.

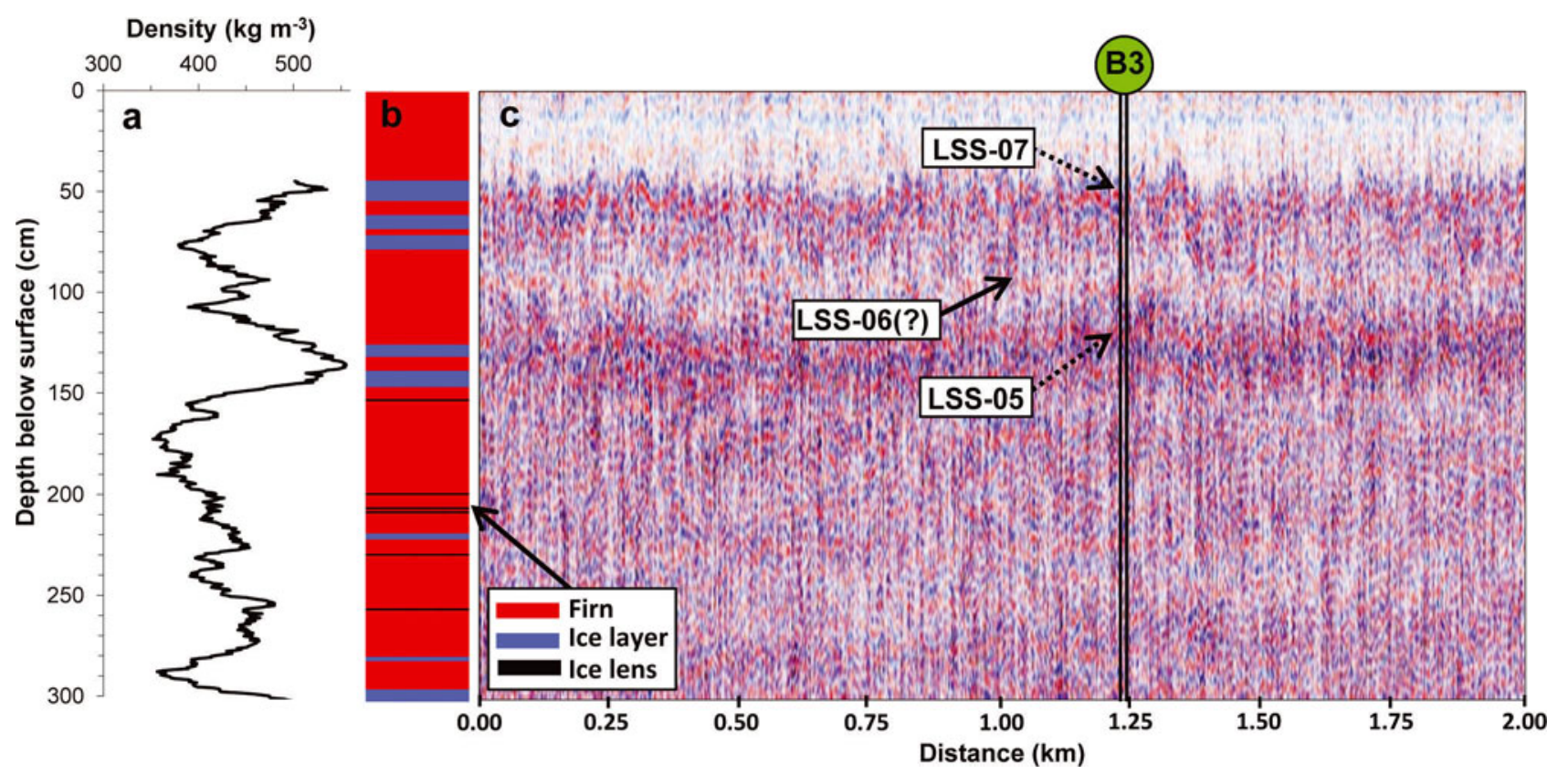

Fig. 3. Results from borehole 3 at $1640 \mathrm{~m}$ : (a) neutron probe density data; (b) visual core stratigraphy; (c) 2 km long GPR trace centered around borehole; dotted arrows point to location of LSS-05 and LSS-07 picked by IcePicker R4 software. Possible location of LSS-06 is marked, but was not picked due to weak return. 

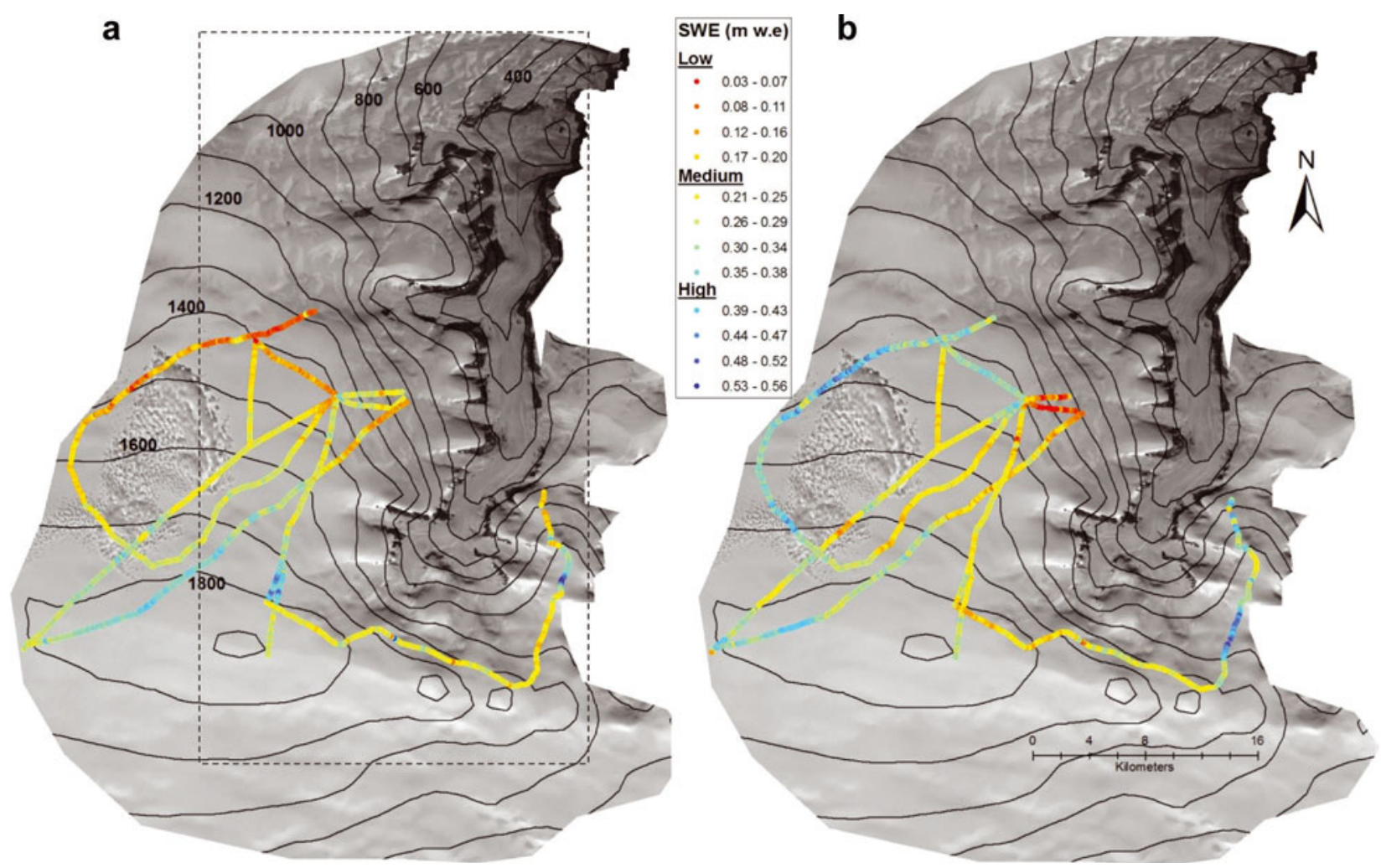

Fig. 4. 1999 Landsat 7 image of Belcher Glacier with $100 \mathrm{~m}$ contours. (a) Winter 2007/08 SWE distribution derived from identification of LSS-07 in the May 2008 GPR transects; dashed box indicates area shown in Figure 5. (b) Net annual (2005-07) SWE distribution derived from the distance between LSS-05 and LSS-07 in the GPR transects, divided by 2 to provide annual values.

\subsection{Winter (2007/08) SWE patterns}

Based on the results presented above, and similar observations from the other GPR transects and boreholes measured in May 2008, we derived winter 2007/08 snow depth for 91889 locations at which GPR traces were recorded in the upper Belcher Glacier basin. These depth measurements were converted to SWE values by multiplying them by the mean density measured in the snow pits of $330 \mathrm{~kg} \mathrm{~m}^{-3}$. As this mean density varied little between pits $\left(\mathrm{SD}= \pm 0.05 \mathrm{~kg} \mathrm{~m}^{-3}\right)$ it was used for all calculations.

The winter 2007/08 SWE varied across Belcher Glacier, typically with higher values at higher elevations (Fig. 4a). SWE values were generally low $(<0.20 \mathrm{~m}$ w.e. $)$ in the lowest parts of the accumulation area (1200-1400 ma.s.I.), but varied between the east and west sides of the basin at higher elevations, with transects in the westernmost part having lower and less variable values than those in the central and eastern parts (Fig. 4a). The largest SWE values were found in the southwest part of the study region (1700-1900 m), near the ice-cap summit, where they were locally $>0.50 \mathrm{~m}$ w.e.

\subsection{Net annual (2005-07) SWE patterns}

As discussed above, additional IRHs were visible below LSS07 in the GPR profiles (Figs 2c and 3c). The returns from the LSS-06 IRH were consistently weaker than those from LSS05, which can be understood by considering the recent melt-refreezing history across Devon Ice Cap. Wolken and others (2009) showed that large-magnitude backscatter $\left(\sigma^{0}\right)$ changes in SeaWinds scatterometer imagery compared to the previous year indicate that extensive ice layer formation occurred on Devon Ice Cap in 2005. Our own decadal ranking of summer (June-August) temperatures at the $700 \mathrm{hPa}$ level using US National Centers for Environmental
Prediction/National Center for Atmospheric Research (NCEP/NCAR) R1 reanalysis data from 1948-2009 shows that 2005 and 2007 were ranked the 4th- and 2nd-warmest summers on record, respectively. The fact that 2005 produced a thick ice layer upon refreezing at the end of summer makes it likely that a similar ice layer was produced in summer 2007 (as was observed in the snow pits). In contrast, 2006 ranked as the 14th-warmest over the period 1948-2009, suggesting that there was less melt available through the summer for the formation of such an ice layer. An additional factor in 2006 was a major rain event of $\sim 38 \mathrm{~mm}$ that occurred in late August across the entire ice cap, which resulted in extensive wet snow metamorphism and the creation of large snow crystals and a highly permeable near-surface (personal communication from D. Burgess, 2010). It is likely that this allowed water to percolate deep into the snowpack and freeze above the impermeable LSS-05 ice layer. Overall this will have produced a weak LSS-06 reflector, but stronger LSS-05 reflector, as observed in the GPR records.

If it is assumed that the next major reflector beneath LSS07 is LSS-05, then it becomes possible to determine the net mass balance for 2005-07 above the firn line. This differs from the 2007/08 records, which represent only winter accumulation, because the 2005-07 series includes two summer melt seasons and indicates what has remained at the end of two full annual cycles. This does not take into account any internal accumulation that might have occurred below LSS-05 due to percolation, although we believe that the thickness of the LSS-05 ice layer will have made it difficult for large volumes of water to penetrate this horizon. The GPR surveys recorded 81118 points at which the distance between the LSS-05 and LSS-07 layers could be 
Table 2. Principal component analysis of the terrain variables at the winter 2007/08 snow depth measurement locations; significant terrain factors are highlighted in bold. Bottom row indicates correlation between winter 2007/08 SWE values and the individual principal components

\begin{tabular}{|c|c|c|c|c|c|c|}
\hline Component & 1 & $\%$ variance & 2 & $\%$ variance & 3 & $\%$ variance \\
\hline Elevation & 0.66 & 43.98 & -0.02 & 0.03 & 0.09 & 0.82 \\
\hline Slope angle & -0.58 & 33.18 & -0.01 & 0.00 & -0.09 & 0.73 \\
\hline North-south scalar & 0.45 & 20.51 & -0.03 & 0.12 & 0.09 & 0.74 \\
\hline East-west scalar & -0.15 & 2.19 & 0.07 & 0.45 & 0.98 & 96.14 \\
\hline Planform curvature $(+=$ convex $)$ & -0.02 & 0.10 & 0.70 & 49.26 & -0.03 & 1.46 \\
\hline Profile curvature $(+=$ concave $)$ & 0.03 & 0.04 & -0.71 & 50.15 & -0.12 & 0.11 \\
\hline Eigenvalue $(\lambda)$ & 1.52 & & 1.32 & & 0.99 & \\
\hline Correlation $(r)$ with 2007/08 SWE & 0.62 & & -0.26 & & 0.62 & \\
\hline
\end{tabular}

determined. These were converted to SWE values using the mean densities recorded in the boreholes between these layers with the neutron probe (Table 1). These SWE values were divided by 2 to provide mean annual net accumulation over a period of 2 years.

There was considerable spatial variability in the SWE distribution for the multi-year time series (Fig. 4b). Over the 2005-07 period, the lowest SWE values occurred in the central part of the Belcher Glacier basin, with the highest values found near the ice-cap summit and in the western part of the basin. The high SWE values found in the western regions in 2005-07 (>0.30 $\left.\mathrm{mw}^{\mathrm{w}} \mathrm{e} . \mathrm{a}^{-1}\right)$ contrasted with the much lower values found in the same area in winter 2007/08 $\left(<0.20 \mathrm{~m}\right.$ w.e. $\left.\mathrm{a}^{-1}\right)$. The greatest horizontal variability in the 2005-07 record occurred in the eastern part of Belcher Glacier, where SWE varied between $<0.20$ and $>0.50 \mathrm{~m}$ w.e. $\mathrm{a}^{-1}$ over one $2 \mathrm{~km}$ section.

\section{DISCUSSION}

\subsection{Influence of terrain on SWE distribution}

To understand the controls on the GPR-derived snow accumulation patterns, we determined the surface topography of Belcher Glacier from a DEM with $20 \mathrm{~m}$ nodal spacing derived from 2007 SPOT-5 (Satellite Pour l'Observation de la Terre) stereo satellite imagery (Korona and others, 2009). The accuracy of the DEM was determined by checking the difference between grid elevations and elevations recorded by the GPS during the GPR surveys. Fifty comparisons were made across the basin, with a mean difference of $5.78 \pm 5.86 \mathrm{~m}$. The terrain factors of slope angle, profile (downslope) curvature, planform (acrossslope) curvature and aspect were calculated from the DEM using ESRI ArcGIS 9.2 software, and extracted for every location at which snow depth was determined from the GPR data. A principal component analysis was performed on these terrain factors to remove the statistical interdependencies between them (Copland, 1998). This indicated that the first three principal components were significant (i.e. $\lambda>1$ ) (Table 2). Component 1 is dominated by the influence of elevation, slope angle and north-south aspect, component 2 by profile and planform curvature, and component 3 by east-west aspect. Together, these three components explain $63.8 \%$ of the total variance in the terrain data.

o determine the relationship between winter 2007/08 SWE distribution (i.e. snow accumulation patterns) and terrain, these first three principal components were correlated with the winter 2007/08 SWE values (Table 2). The resulting correlation coefficients were all statistically significant at $>99 \%$, and indicate that SWE is positively correlated $(r=0.62)$ with PC1, which indicates that SWE tends to increase as altitude increases and slope angle declines, so that the deepest snow is found in the upper, gently sloping regions of the basin that are predominantly north-facing. Elevation has previously been recognized as an important influence on variations in snow depth distribution over Devon Ice Cap and within the QEI more generally (Mair and others, 2005; Colgan and Sharp, 2008; Colgan and others, 2008), most likely due to the forced mechanical lifting of air as it passes over the ice cap (Elder and others, 1991).

SWE is negatively correlated $(r=-0.26)$ with PC2, the factor that mainly represents surface curvature. SWE tends to be higher in concave areas such as gullies, likely due to wind redistribution. These findings complement those of Koerner (1966) and Koerner and Russell (1979), who found that snow accumulation patterns across Devon Ice Cap can be strongly influenced by wind scour, particularly in the winter. In a study near Resolute Bay, QEI, Woo and others (1983) also found that annual snow deposits were shallowest $(<0.1 \mathrm{~m})$ on windswept hilltops or convex ridges, and thickest $(>1.0 \mathrm{~m})$ in concave gullies and valleys.

SWE is positively correlated $(r=0.62)$ with PC3, which indicates that SWE tends to increase on east-facing slopes. This may be related to the dominant northwest winds on Devon Ice Cap (Wohlleben, 2009) depositing snow in leeside locations.

\subsection{Determination of glacier facies with GPR}

Changes in the location and characteristics of IRH can be used to determine the location of the firn line across the Belcher Glacier basin. In particular, the depth to LSS layers decreases from the accumulation area towards the ablation zone, as indicated by distinct IRHs that intersect the glacier surface in the GPR profiles (Fig. 5). In the main accumulation area the near-surface is composed of a firn/snow matrix that was visible as a zone of high backscatter in GPR records. Decimeter-scale variations in near-surface density in the upper part of the accumulation zone cause the GPR signal to be reflected and attenuated at the multiple interfaces between compacted firn, ice layers and ice lenses, as observed in borehole stratigraphy (Figs $2 \mathrm{~b}$ and $3 \mathrm{~b}$ ). In the Belcher Glacier basin, Burgess and Sharp (2008) used aerial photography and field observations to map a system of 


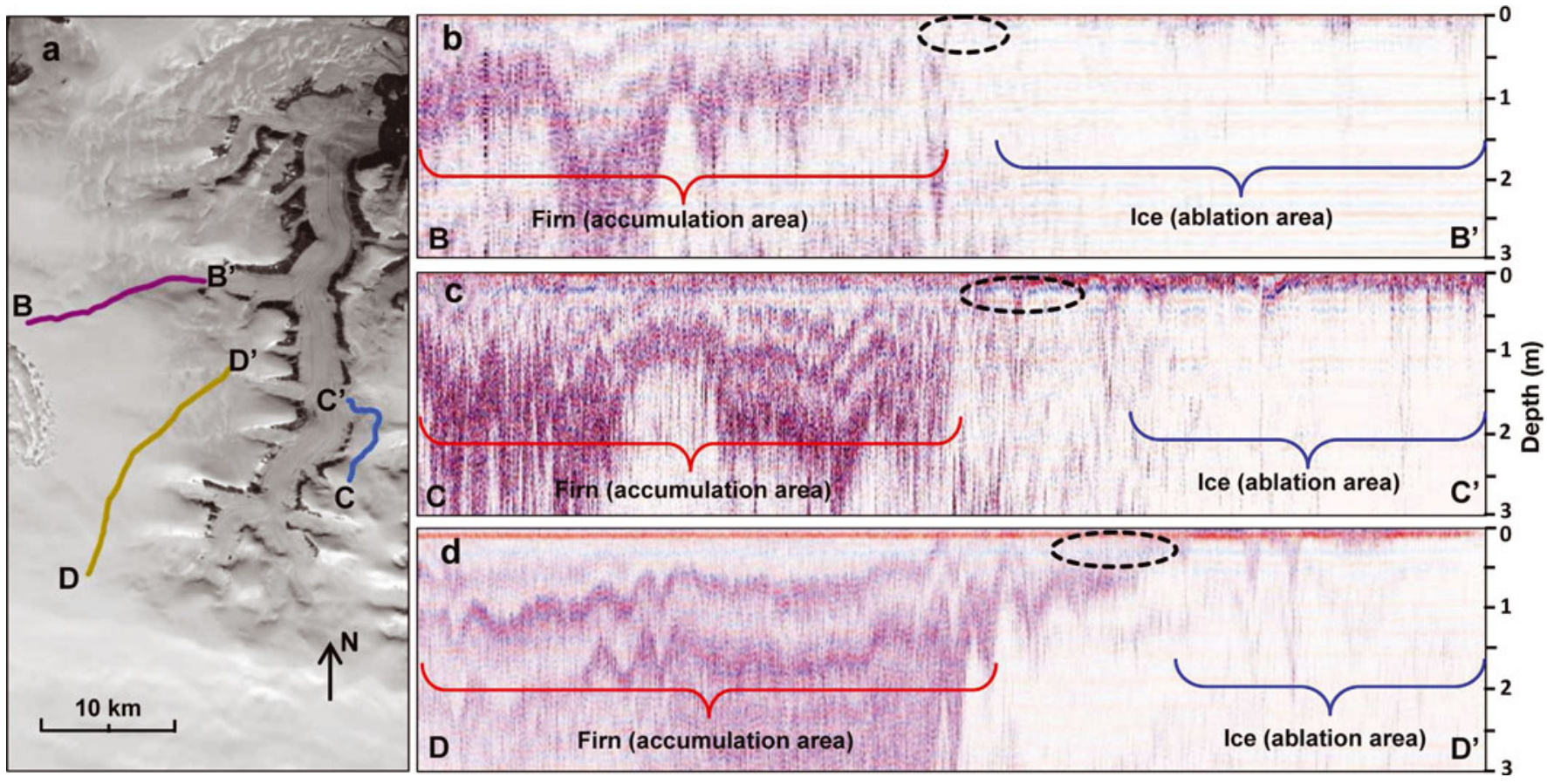

Fig. 5. Examples of $500 \mathrm{MHz}$ GPR transects where the firn line (dotted black ellipse) can be identified from IRH intersecting the glacier surface: (a) location of transects (see Fig. 4a for image extent); (b) $14 \mathrm{~km}$ long transect from B to B', with firn line at $1275 \mathrm{~m}$; (c) $8.5 \mathrm{~km}$ long transect from $C$ to $C^{\prime}$, with firn line at $1264 \mathrm{~m}$; (d) $19 \mathrm{~km}$ long transect from $\mathrm{D}$ to $\mathrm{D}^{\prime}$, with firn line at $1271 \mathrm{~m}$. Intermittent returns in the region between the areas marked as firn and ice likely reflect the superimposed ice zone. Note that transects shown in this figure reach lower elevations than those used to derive SWE patterns in Figures 1 and 4.

meltwater channels that begin at $\sim 1500 \mathrm{~m}$ elevation and terminate in crevasse fields and moulins at lower elevations. Surface meltwater and slush flows originating in these channels would refreeze on the surface at the end of the summer, causing a series of thick ice layers and lenses interspersed with firn. Consequently, the GPR record tends to be particularly cluttered by noisy returns at altitudes of 1260-1450 m. In contrast, radar returns at lower elevations displayed much lower backscatter as the solid ice there is almost transparent to radio-frequency energy. Similarly, Langley and others (2008) and Dunse and others (2009) used distinct reflectors in GPR records from Austfonna, Svalbard, and Kongsvegen Glacier, Greenland, respectively, to characterize glacier facies beneath the winter snow and to distinguish the location of the firn line.

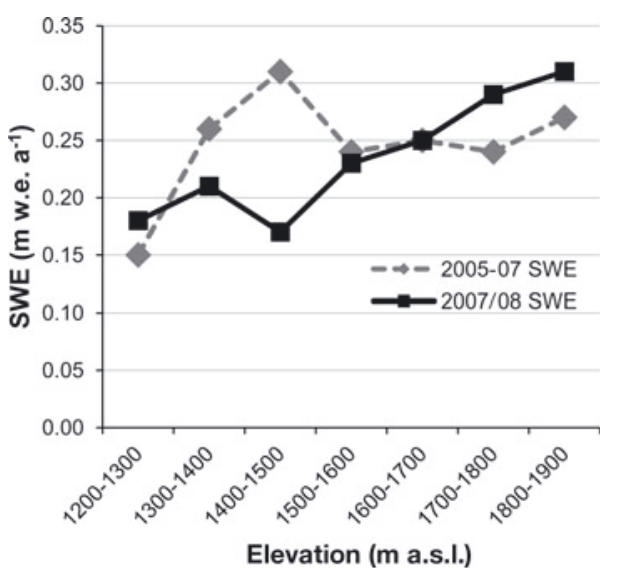

Fig. 6. Variability in SWE across Belcher Glacier for net annual (2005-07) and winter (2007/08) periods. Only values above the firn line $(1260 \mathrm{~m})$ are shown.
The transition between firn and ice facies represents the firn line, and occurred consistently at elevations of 1260$1300 \mathrm{~m}$ across the Belcher Glacier basin. At elevations below $1260 \mathrm{~m}$ the first layer (LSS-07) could be seen intermittently, but neither the second layer (LSS-05) nor any deeper ones could be tracked. This region of intermittent internal reflections likely indicates superimposed ice formation, with the ablation area occurring below this region where there were no internal reflections because the entire surface accumulation is removed each year. Since the superimposed ice zone represents a region of net annual accumulation, the equilibrium-line altitude occurs at the base of this zone and cannot be easily identified in the GPR traces.

\subsection{Mass-balance patterns across the Devon Ice Cap accumulation area}

To enable comparisons with earlier mass-balance studies on Devon Ice Cap, we determined net annual snow accumulation over the period 2005-07 by averaging the accumulation rate for each $100 \mathrm{~m}$ elevation band across that part of the Belcher Glacier basin above the firn line (Fig. 6; Table 1). To convert snow depths to SWE values for these calculations, we used a snow density that varied with altitude based on the neutron probe records from the nearest borehole (Table 1). The 2005-07 net annual accumulation rate of $0.27 \mathrm{~m}$ w.e. $\mathrm{a}^{-1}$ in the summit region was a little higher than rates of $0.25,0.24,0.23$ and $0.22 \mathrm{mw} . e . \mathrm{a}^{-1}$ found in previous studies that used shallow ice coring (respectively Koerner, 1977; Pinglot and others, 2003; Mair and others, 2005; Colgan and Sharp, 2008). Direct comparisons are more problematic at lower altitudes as no previous longterm accumulation measurements have been made in the Belcher Glacier basin, and there is a strong gradient in accumulation rates across the ice cap between peaks in the 
southeast and minima in the northwest. This is related to distance from the primary moisture source of Baffin Bay and the North Open Water Polynya (Koerner, 1966). For example, Mair and others (2005) found long-term (1963-2000) accumulation rates on Devon Ice Cap of $0.27 \mathrm{~m}$ w.e. $\mathrm{a}^{-1}$ at an altitude of $1325 \mathrm{~m}$ to the south of the summit, but rates of $0.13 \mathrm{~m}$ w.e. $\mathrm{a}^{-1}$ at an altitude of $1340 \mathrm{~m}$ to the northwest of the summit. Accumulation rates at Belcher Glacier likely lie somewhere between these extremes given its location relative to Baffin Bay.

To assess winter snow accumulation patterns, we also calculated the winter 2007/08 SWE patterns for each elevation band using the GPR-derived snow depths and average density of $330 \mathrm{~kg} \mathrm{~m}^{-3}$ measured in the snow pits (Fig. 6). These show a clear relationship to altitude, with a peak of $0.31 \mathrm{~m}$ w.e. at the summit. If snow accumulation rates were constant over time, we would expect the 200507 net annual values to be lower than these winter values due to the influence of summer melt. However, Figure 6 indicates that the 2005-07 net annual rates were higher at some altitudes, particularly over the range 1300-1500 m. We believe that this may be related to the effects of wind redistribution. Koerner (1966) and Mair and others (2005) describe how katabatic winds can scour the snow from the upper parts of the ice cap from $\sim 1600$ to $1800 \mathrm{~m}$ (but not right at the summit), with deposition of this snow at elevations below $1600 \mathrm{~m}$. This is consistent with the patterns observed in our data (Fig. 6), and our own observations of the occurrence of blowing snow in the field. We do not have sufficient data to explain why this pattern is not observed in the winter data, but hypothesize that it may be related to the dominance of these winds during the spring and summer.

\section{CONCLUSIONS}

This study has demonstrated that $500 \mathrm{MHz}$ GPR provides an effective method of mapping glacier facies, the firn-line elevation and both winter (2007/08) and net annual (200507) snow accumulation patterns across Belcher Glacier. The dominant shallow IRH in our GPR traces equates to the nearsurface crust formed at the end of the previous (2007) summer. The depth of winter snow determined by GPR agrees well with manual point measurements made using an avalanche probe, and deeper layering agrees well with icecore stratigraphy and densities measured with a neutron probe (Figs 2 and 3). GPR measurements have previously provided similar information elsewhere in the Arctic and Antarctic, but the technique has not previously been used to reconstruct annual or winter accumulation patterns in the Canadian Arctic. The results presented here suggest that GPR could provide an effective method to detect glacier facies distributions and measure snow accumulation patterns across large regions of ice caps in other locations in the Canadian Arctic (e.g. Baffin, Ellesmere and Axel Heiberg Islands) that would improve on existing point measures.

The firn-line elevation across Belcher Glacier ranged from 1260 to $1300 \mathrm{~m}$ during the period 2005-08. Elevation was the dominant control on winter snow accumulation patterns, although other factors (e.g. surface curvature and aspect) were also locally important. Net annual mass balance over the period 2005-07 ranged between $0.15 \pm 0.10$ and $0.31 \pm 0.09 \mathrm{~m}$ w.e. $\mathrm{a}^{-1}$ for elevations from 1260 to $1900 \mathrm{~m}$, with an average of $0.24 \mathrm{~m}$ w.e. $\mathrm{a}^{-1}$. These values appear to be a little higher than those found in previous studies on Devon
Ice Cap, but given the lack of past measurements in the Belcher Glacier basin and natural intra-annual variability in snow accumulation patterns, there are no temporal trends that exceed the $\sim 15-20 \%$ error limits of our study.

\section{ACKNOWLEDGEMENTS}

We thank the Canada Foundation for Innovation, the Ontario Research Fund, the Natural Sciences and Engineering Research Council of Canada (International Polar Year (IPY) Special Research Opportunity, Discovery Grant Program and Northern Research Supplement), the Northern Scientific Training Program, the Polar Continental Shelf Program (this is PCSP contribution No. 033-11), the University of Ottawa and the Canadian Space Agency (Government Related Initiatives Program (GRIP) funding to Demuth) for financial and logistic support. This is Natural Resources Canada Earth Sciences Center (ESS) contribution No. 20110344. We also thank John Sekerka (Geological Survey of Canada), Wesley van Wychen and Emilie Herdes for contributions to fieldwork. We are grateful for access to SPOT-5 data provided by the SPIRIT (SPOT-5 stereoscopic survey of Polar Ice: Reference Images and Topographies) project. Detailed and constructive reviews by Thorben Dunse, Steve Arcone and other anonymous reviewers greatly improved the manuscript.

\section{REFERENCES}

Anschütz $H$, Steinhage $D$, Eisen $O$, Oerter $H$, Horwath $M$ and Ruth U (2008) Small-scale spatio-temporal characteristics of accumulation rates in western Dronning Maud Land, Antarctica. J. Glaciol., 54(185), 315-323 (doi: 10.3189/ 002214308784886243)

Arcone SA, Spikes VB, Hamilton GS and Mayewski PA (2004) Stratigraphic continuity in $400 \mathrm{MHz}$ short-pulse radar profiles of firn in West Antarctica. Ann. Glaciol., 39, 195-200 (doi: 10.3189/172756404781813925)

Arcone SA, Spikes VB and Hamilton GS (2005) Stratigraphic variation in polar firn caused by differential accumulation and ice flow: interpretation of a $400 \mathrm{MHz}$ short-pulse radar profile from West Antarctica. J. Glaciol., 51(174), 407-422 (doi: 10.3189/172756505781829151)

Bell JP (1969) A new design principle for neutron soil moisture gauges: the Wallingford neutron probe. Soil Sci., 103(3), 160-164

Burgess D and Sharp MJ (2008) Recent changes in thickness of the Devon Island ice cap, Canada. J. Geophys. Res., 113(B7), B07204 (doi: 10.1029/2007JB005238)

Cogley JG, Adams WP, Ecclestone MA, Jung-Rothenhäusler F and Ommanney CSL (1996) Mass balance of White Glacier, Axel Heiberg Island, N.W.T., Canada, 1960-1991. J. Glaciol., 42(142), 548-563

Colgan W and Sharp M (2008) Combined oceanic and atmospheric influences on net accumulation on Devon Ice Cap, Nunavut, Canada. J. Glaciol., 54(184), 28-40 (doi: 10.3189/002214308784409044)

Colgan W, Davis J and Sharp M (2008) Is the high-elevation region of the Devon Ice Cap thickening? J. Glaciol., 54(186), 428-436 (doi: 10.3189/002214308785837084)

Copland L (1998) The use of terrain analysis in the evaluation of snow cover over an alpine glacier. In Lane SN, Richards KS and Chandler JH eds. Landform monitoring, modelling and analysis. Wiley, Chichester, 385-404

Deems JS, Fassnacht SR and Elder K (2006) Fractal distribution of snow depth from LiDAR data. J. Hydromet., 7(2), 285-297 (doi: 10.1175/JHM487.1)

Demuth MN, Marshall H-P and Morris EM (2007) High-resolution near-surface snow stratigraphy inferred from ground-based 
8-18 GHz FMCW radar measurements: Devon Ice Cap, Nunavut, Canada 2005-06, CryoSat Validation Experiment. In Hellström R and Frankenstein S eds. Proceedings of the 64th Eastern Snow Conference, 29 May-1 June 2007, St John's, Newfoundland, Canada. Cold Regions Research and Engineering Laboratory, Hanover, $\mathrm{NH}, 9-16$

Dunse T, Eisen O, Helm V, Rack W, Steinhage D and Parry V (2008) Characteristics and small-scale variability of GPR signals and their relation to snow accumulation in Greenland's percolation zone. J. Glaciol., 54(185), 333-342 (doi: 10.3189/ 002214308784886207)

Dunse T, Schuler TV, Hagen JO, Eiken T, Brandt O and Høgda KA (2009) Recent fluctuations in the extent of the firn area of Austfonna, Svalbard, inferred from GPR. Ann. Glaciol., 50, 155-162 (doi: 10.3189/172756409787769780)

Eisen $\mathrm{O}$ and 15 others (2008) Ground-based measurements of spatial and temporal variability of snow accumulation in East Antarctica. Rev. Geophys., 46(RG2), RG2001 (doi: 10.1029/ 2006RG000218)

Elder K, Dozier J and Michaelsen J (1991) Snow accumulation and distribution in an alpine watershed. Water Resour. Res., 27(7), 1541-1552 (doi: 10.1029/91WR00506)

Hawley RL, Morris EM, Cullen R, Nixdorf U, Shepherd AP and Wingham DJ (2006) ASIRAS airborne radar resolves internal annual layers in the dry-snow zone of Greenland. Geophys. Res. Lett., 33(4), L04502 (doi: 10.1029/2005GL025147)

Hawley RL, Brandt O, Morris EM, Kohler J, Shepherd AP and Wingham DJ (2008) Techniques for measuring highresolution firn density profiles: a case study from Kongsvegen, Svalbard. J. Glaciol., 54(186), 463-468 (doi: 10.3189/ 002214308785837020)

Koerner RM (1966) Accumulation on the Devon Island ice cap, Northwest Territories, Canada. J. Glaciol., 6(45), 383-392

Koerner RM (1977) Devon Island ice cap: core stratigraphy and paleoclimate. Science, 196(4285), 15-18 (doi: 10.1126/ science.196.4285.15)

Koerner RM and Russell RD (1979) $\delta^{18} \mathrm{O}$ variations in snow on the Devon Island ice cap, Northwest Territories, Canada. Can. J. Earth Sci., 16(7), 1419-1427

Kohler J, Moore J, Kennett M, Engeset R and Elvehøy H (1997) Using ground-penetrating radar to image previous years' summer surfaces for mass-balance measurements. Ann. Glaciol., 24, 355-360

Korona J, Berthier E, Bernard M, Rémy F and Thouvenot E (2009) SPIRIT. SPOT 5 stereoscopic survey of polar ice: reference images and topographies during the fourth International Polar Year (2007-2009). ISPRS J. Photogramm. Remote Sens., 64(2), 204-212 (doi: 10.1016/j.isprsjprs.2008.10.005)

Kovacs A, Gow AJ and Morey RM (1995) The in-situ dielectric constant of polar firn revisited. Cold Reg. Sci. Technol., 23(3), 245-256 (doi: 10.1016/0165-232X(94)00016-Q)

Langley K and 6 others (2008) From glacier facies to SAR backscatter zones via GPR. IEEE Trans. Geosci. Remote Sens., 46(9), 2506-2516 (doi: 10.1109/TGRS.2008.918648)

Mair D, Burgess D and Sharp M (2005) Thirty-seven year mass balance of Devon Ice Cap, Nunavut, Canada, determined by shallow ice coring and melt modelling. J. Geophys. Res., 110(F1), F01011 (doi: 10.1029/2003JF000099)

Maurer JAI (2006) Local-scale snow accumulation variability on the Greenland ice sheet from ground-penetrating radar (GPR). (MA thesis, University of Colorado)

Morris EM (2008) A theoretical analysis of the neutron-scattering method for measuring snow and ice density. J. Geophys. Res., 113(F3), F03019 (doi: 10.1029/2007JF000962)

Morris EM and Cooper JD (2003) Density measurements in ice boreholes using neutron scattering. J. Glaciol., 49(167), 599-604 (doi: 10.3189/172756503781830403)

Pälli A and 6 others (2002) Spatial and temporal variability of snow accumulation using ground-penetrating radar and ice cores on a Svalbard glacier. J. Glaciol., 48(162), 417-424 (doi: 10.3189/ $172756502781831205)$

Parry V and 6 others (2007) Investigations of meltwater refreezing and density variations in the snowpack and firn within the percolation zone of the Greenland ice sheet. Ann. Glaciol., 46, 61-68 (doi: 10.3189/172756407782871332)

Pinglot JF, Hagen JO, Melvold K, Eiken T and Vincent C (2001) A mean net accumulation pattern derived from radioactive layers and radar soundings on Austfonna, Nordaustlandet, Svalbard. J. Glaciol., 47(159), 555-566 (doi: 10.3189/ 172756501781831800)

Pinglot JF and 13 others (2003) Ice cores from Arctic sub-polar glaciers: chronology and post-depositional processes deduced from radioactivity measurements. J. Glaciol., 49(164), 149-158 (doi: 10.3189/172756503781830944)

Spikes VB, Hamilton GS, Arcone SA, Kaspari S and Mayewski P (2004) Variability in accumulation rates from GPR profiling on the West Antarctic plateau. Ann. Glaciol., 39, 238-244 (doi: 10.3189/172756404781814393)

Taurisano A and 6 others (2007) The distribution of snow accumulation across Austfonna ice cap Svalbard: direct measurements and modelling. Polar Res., 26(1), 7-13 (doi: 10.1111/j.1751-8369.2007.00004.x)

Van Wychen W, Copland L, Gray L, Burgess D, Danielson B and Sharp M (2012) Spatial and temporal variation of ice motion and ice flux from Devon Ice Cap, Nunavut, Canada. J. Glaciol., 58(210), 657-664 (doi: 10.3189/2012JoG11J164)

Wang L, Sharp MJ, Rivard B, Marshall S and Burgess D (2005) Melt season duration on Canadian Arctic ice caps, 20002004. Geophys. Res. Lett., 32(19), L19502 (doi: 10.1029/ 2005GL023962)

Wohlleben TMH (2009) Ice-atmosphere interactions in the Canadian High Arctic: implications for the thermo-mechanical evolution of terrestrial ice masses. (PhD thesis, University of Alberta)

Wolken GJ, Sharp M and Wang L (2009) Snow and ice facies variability and ice layer formation on Canadian Arctic ice caps, 1999-2005. J. Geophys. Res., 114(F3), F03011 (doi: 10.1029/ 2008JF001173)

Woo MK, Heron R, Marsh P and Steer P (1983) Comparison of weather station snowfall with winter snow accumulation in High Arctic basins. Atmos.-Ocean, 21(3), 312-325 (doi: 10.1080/07055900.1983.9649171) 7981 